\title{
Severe preeclampsia: obstetric critical care unit of "hospital general de México" experience during 2014
}

\begin{abstract}
Background: Preeclampsia is the leading cause of maternal mortality, which physiopathology includes neurological, hemodynamics, renal, hepatic and hematological impairment such as important fetal compromise. The only definitive treatment is the pregnancy interruption, and the primary objectives are to define the moment and interruption manner.

The protocol of treatment in Obstetric Critical Care Unit of "Hospital General de México" (UCIGO) is based in three pillars:
A. Plasmatic volume expansion,
B. Bringing down the systemic vascular resistances and
C. Organ specific protection.

The objective of this paper is to describe the experience in severe preeclampsia in UCIGO during the period January 01, 2014-January 01, 2015.

Results: During the study period 154 patients were included with diagnoses of severe preeclampsia; it is worth mentioning that only there was one maternal death, with a mortality of $0.65 \%$. There was not any fetal loss related to severe preeclampsia.

Conclusion: The UCIGO has the Obstetric Critical Care Program, with the endorsement of the National Autonomous University of Mexico. This novel specialty is oriented to treat the physiopathological acute alterations that threaten life, in pregnant women with diseases or unfavorable obstetric events.
\end{abstract}

Keywords: preeclampsia, mortality, obstetric critical care
Special Issue - 2015

\begin{abstract}
Jose Antonio Viruez Soto,' Carla María Vallejo Narvaez,' Carlos Briones Vega, ${ }^{2}$ Jesus Carlos Briones Garduno, ${ }^{3}$ Manuel Antonio Díaz de Leon Ponce ${ }^{4}$

'Obstetric Critical Care Unit of Hospital General de Mexico Dr. Eduardo Liceaga, Mexico

${ }^{2}$ Chief of Maternal Fetal Unit of the Genetics and Infertility Institute, Mexico

${ }^{3}$ Mexican National Academy of Medicine, Mexican Academy of Surgery, Chief of the Obstetric Critical Care Unit of "Hospital General de Mexico Dr. Eduardo Liceaga. Professor of the specialty of Obstetric Critical Care of the Autonomous University of Mexican State and the National Autonomous University of Mexico

${ }^{4}$ Mexican National Academy of Medicine, Mexican Academy of Surgery, Ex Chief of the Medicine and Acute Medicine Units of National Medical Center XXI Century" of Social Security Institute. Ex-President of Mexican Nephrology and Critical Care Colleges
\end{abstract}

Correspondence: José Antonio Viruez Soto, Dr. Lucio \#240 Street, Int 6, Doctores Colony, Cuauhtémoc Delegation, México Federal District, Mexico, Tel 5566289773,

Email antonioviruez@hotmail.com

Received: February 25, 2015 | Published: September 16, 2015

\section{Introduction}

Preeclampsia is the leading cause of maternal mortality. It is a medical neologism that means "before the lightning", in a classic way it is mentioned that appears after the 20th week of pregnancy, however it could happen before in trophoblastic disease or multiple gestation, and it also could appear during delivery and until 2 weeks of puerperium. The denomination of toxemia is unappropriated, because there is not a toxin detected till this moment. ${ }^{1-3}$

\section{Physiopathology}

The direct cause is still unknown. Preeclampsia is characterized by vasoconstriction, hemoconcentration and ischemic changes in placenta, brain, kidney and liver. The most accepted theory is an alteration during the placentation with the smooth muscle cells conservation of the uterine spiral arteries related to a defective trophoblastic invasion. ${ }^{4,5}$ The multisystemic impairment is characterized by:

Neurological: Hypertensive and/or ischemic encephalopathy due to vasoconstriction that can produce eclamptic seizures, not related directly to vasospasm. ${ }^{6}$ Imaging sometimes demonstrates cerebral oedema in the posterior region which explains the visual alterations in preeclampsia as blurred vision, scotoma, transient blindness and headache (denominated as posterior reversible encephalopathy syndrome). An important indicator of neurological impairment is hyperreflexia.?
Hemodynamics: Intense systemic vasoconstriction due to vascular hyperactivity with imbalance between vasoconstrictors substances (endothelin, thromboxane) and vasodilators (prostacyclin, nitric oxide). An important characteristic is hemoconcentration that reduces tolerance to delivery blood loss. Severe preeclampsia presents hemoconcentration (due to capillary leak), hypodynamic pattern with low cardiac index/output and increased vascular systemic resistances with diastolic dysfunction associated. Those are the reasons because of inotropic, according the patient characteristics, should be considered. ${ }^{8}$

Renal: Vasoconstriction with decreased renal perfusion can produce even acute tubular necrosis.

Hepatic: Liver enzymes elevated caused by ischemia, associated with subcapsular hematomas and hepatic rupture. Biopsy demonstrates ischemic lesions, periportal haemorrhage and fibrin deposition.

Hematological: Thrombocytopenia related to microangiopathic syndrome and intravascular hemolysis expressed by schistocytesin peripheral blood smear and reduction of haptoglobin (by its union to plasmatic free hemoglobin). The interpretation of basal hemoglobin on a preeclamptic patient must be done carefully, a low hematocrit should express hemolysis and higher hemoglobin must be related to hemoconcentration.

Effects on the fetus: As an expression of a poor placental function, it should exist. 
Acute fetal distress: Expressed by meconium elimination.

Restricted fetal growth: As manifestation of chronic fetal distress, more important if preeclampsia installed early at pregnancy.

Perinatal mortality: Related to complications of preeclampsia.

\section{Identified risk factors for preeclampsia}

First pregnancy, intergenesic period $>10$ years, trophoblastic disease, multiple gestation, maternal age $>40$ years, multiparity, chronic arterial hypertension, chronic renal insufficiency, diabetes mellitus, obesity, autoimmune disorders congenital or acquired thrombophilia, infections during pregnancy, pregnancy due to donor semen or egg donation, preeclampsia history or familiar history of preeclampsia. Recurrence of preeclampsia affects women with intergestational period $<2$ years or $\geq 10$ years. $1-4$

Diagnosis: diagnostic criteria, from 20 weeks:

\section{Arterial hypertension}

a. $\geq 140 / 90(106) \mathrm{mmHg}$ in two occasions with interval of 4 hours.

b. $\geq 160 / 110(126) \mathrm{mmHg}$ to be confirmed in a shorter period of time looking forward to initiate antihypertensive treatment.

Proteinuria: Nowadays there is debate considering it a diagnostic criterion, however it should be considered if it is $\geq 300 \mathrm{mg} /$ day or its equivalent in a shorter time, labstix $\geq(+)$ or proteins/creatinine ratio $\geq 0.3$ (both in $\mathrm{mg} / \mathrm{dL}$ ).

In lack of hypertension or proteinuria, following should be considered.

\section{Thrombocytopenia: $<100000 / \mathrm{mm}^{3}$.}

Hepatopathy: Elevated transaminases twice or more.

Renal insufficiency: Creatinine $>1.1 \mathrm{mg} / \mathrm{dL}$ or elevation twice of the basal creatinine, in absence of prior renal disease.

Pulmonary oedema: Secondary to hemodynamic failure and capillary leak.

Cerebral or visual impairment: Includes hyperreflexia, nauseas, vomiting, persistent severe headache, scotoma, phosphene, tinnitus, blurred vision, impaired consciousness.

Signs and symptoms: Epigastric or right hypochondrial persistent pain, dyspnea, vaginal haemorrhage, decreased fetal movements, ovular membranes rupture.

\section{Ancillary tests}

It is worth to consider hematic biometry, blood chemistry with determination of creatinine, urea, uric acid, creatinine clearance, bilirubin, transaminases, alkaline phosphatase, gamma glutamyl transpeptidase, prothrombin time, activated partial thromboplastintime, platelets, fibrinogen, chest radiography, fetal biophysical profile (amniotic liquid determination), Doppler flowmetry, evaluate pulsatility index and presence of notch, brain tomography and/or magnetic resonance, colloid osmotic pressure (COP) that is obtained easily from the Landis-Pappenheimer formula and total protein concentration (TP); $\mathrm{COP}=2.38(\mathrm{TP})+0.138(\mathrm{TP}) 2+0.00957(\mathrm{TP}) 3$ and also Briones' Index (BI) that results of the quotient of $\mathrm{COP} /$ mean arterial pressure. In preeclamptic patients OCP lower than $15 \mathrm{mmHg}$ and a BI lower than $0.11 \mathrm{mmHg}$, are associated to greater maternal- fetal morbidity and mortality. ${ }^{9-11}$ Uric acid $\geq 6 \mathrm{mg} / \mathrm{dL}$ is considered a maternal fetal prognosis factor. Authors suggest hemodynamic monitoring with thoracic bioimpedance as noninvasive preferred method.

Severe preeclampsia or preeclampsia with severity criteria is considered in case of:
i. Hypertension $\geq 160 / 110 \mathrm{mmHg}$ twice with 4 hour-interval
ii. Cerebral or visual impairment
iii. Pulmonary oedema
iv. Serum creatinine $>1.1 \mathrm{mg} / \mathrm{dL}$
v. Thrombocytopenia $\leq 100000 / \mathrm{mm}^{3}$
vi. Elevation of hepatic enzymes twice or more
vii. Epigastric or right hypochondrial persistent pain

On treatment, until this moment, the only definitive treatment is pregnancy interruption, and the primary objectives are to define the moment and interruption manner.

The protocol of treatment in Obstetric Critical Care Unit of "Hospital General de México" (UCIGO) is based in three pillars, called the "ABC protocol":

Plasmatic volume expansion: Not only with crystalloids, but also with colloids, mainly albumin looking for improvement in colloid osmotic pressure, Briones' index and decrease capillary leak.

Bringing down the systemic vascular resistances (antihypertensives): The objective is mean arterial pressure $\leq 105 \mathrm{mmHg}$. The hemoconcentrated patients, at receiving vasodilators of rapid action (hydralazine or nifedipine) could present excessive hypotension with secondary reduction of tissue perfusion and uterine-placental blood flow, it is important the administration of $250-500 \mathrm{ml}$ of $0.9 \%$ saline solution $0.9 \%$ before the vasodilators. The hypertensive emergency (blood pressure $\geq 220 / 120[153] \mathrm{mmHg}$ ) is frequently associated to hypertensive encephalopathy, acute left ventricular insufficiency, pulmonary oedema, aortic acute dissection, angina, acute myocardial infarction, ventricular arrhythmias, placental abruption, intravascular disseminated coagulation, necrosis of glomerular efferent arteries with haemorrhage on renal marrow and cortex with fibrinoid necrosis, proliferative endarteritis, proteinuria, oliguria, hematuria and hyaline or hematic cylinders with progressive uremia.

In particular, the hypertensive encephalopathy has an acute onset during 24-72hours and can be associated to retinal haemorrhage, retinal infarctions and papiledema with visual impairment. The treatment of hypertension should be progressive considering hydralazine, nifedipine, metoprolol, prazosin, labetalol and alfametildopa. In case of hypertensive emergency and hypertensive encephalopathy intravenous treatment with sodium nitroprusside, nitroglycerine or labetalol, should be initiated.

Organ specific protection: Includes brain, lung, heart and coagulation protection with specific treatment.

Neuroprotection: With magnesium sulfate orphenytoin, this last does not increase the risk of uterine hypotonia.

Pulmonary oedema: Consider the administration of albumin followed by furosemide in cases of capillary leak and hydric overload. 
Cardiac output optimization: Prevents associated complications, consider inotropic depending the case (levosimendan, digoxin, dobutamine). ${ }^{12}$

Thrombocytopenia: In cases with thrombocytopenia $<100000$ / $\mathrm{mm}^{3}$, it should be considered dexamethasone according the physician experience, for example $8 \mathrm{mg}$ intravenous (IV)q $/ 8 \mathrm{~h}$ or $10 \mathrm{mg} \mathrm{IV} \mathrm{q} / 12 \mathrm{~h}$, anyway the objective is to administer $\geq 20 \mathrm{mg}$ in 24 hours during 2 or more days. It is not recommended to initiate transfusions of platelets concentrates when platelets are $>50000 / \mathrm{mm}^{3}$, except in rapid decreasing or important hemolysis. The risk of hemorrhage during delivery and cesarean is high with platelets $<20,000 / \mathrm{mm}^{3}$ and platelet transfusion should be considered. Platelets count lower of 75,000 / $\mathrm{mm} 3$ are associated to epidural hematoma related to anesthetic procedures. $^{13}$

Thromboprophylaxis: Consider low height molecular heparin or non fractionated heparin.

Fetal lung maturation: It should be considered in 27-33.6 weeks, with betamethasone $12 \mathrm{mg}$ intramuscular (IM) $\mathrm{q} / 24 \mathrm{~h}$ for two doses, dexamethasone $6 \mathrm{mg}$ IM q/12h for 3 doses or dexamethasone $12 \mathrm{mg}$ $\mathrm{IMq} / 24 \mathrm{~h}$ for 2 doses with latency period at least 24 hoursbefore pregnancy interruption. Some guides consider even hydrocortisone $500 \mathrm{mg} \mathrm{IVq} / 12 \mathrm{~h}$ for 4 doses. ${ }^{3,4,9}$

Severe preeclampsia complications: Include eclampsia, thrombotic mycroangiopathy and intravascular hemolysis (also known as HELLP "syndrome" that corresponds to the acronym referred to just one part of the physiopathology of severe preeclampsia), disseminated intravascular coagulation, intracranial haemorrhage, renal insufficiency, pulmonary oedema, hepatic rupture, retinal detachment, placental abruption and maternal-fetal death. ${ }^{9,10}$

The objective of this paper is to describe the experience in severe preeclampsia in Obstetric Critical Care Unit of "Hospital General de México Dr. Eduardo Liceaga" (UCIGO) during the period January 01, 2014-January 01, 2015.

\section{Patients and methods}

All patients with diagnosis of severe preeclampsia admitted to UCIGO during the study period received the treatment according the protocol "ABC" of the Unit, also according to the Clinical Practice Guides of the Mexican Ministry of Health, compound of (explained with details in the introduction section):

a) Plasmatic volume expansion.

b) Bringing down the systemic vascular resistances.

c) Specific organ protection.

The diagnoses and characteristics of the patients included in this case series are expressed in Table 1.

Table I Patient's characteristics

\begin{tabular}{lllll}
\hline Variables & Average & $\begin{array}{l}\text { Inferior- } \\
\text { superior } \\
\text { limits }\end{array}$ & $\begin{array}{l}\text { Statistical } \\
\text { rank }\end{array}$ & $\begin{array}{l}\text { Standard } \\
\text { deviation }\end{array}$ \\
\hline Age (years) & 27 & $17-43$ & 26 & 4.56 \\
$\begin{array}{l}\text { Gestational } \\
\text { Age (weeks) }\end{array}$ & 35 & $26-41$ & 15 & 3.83 \\
$\begin{array}{l}\text { UCIGO Stay } \\
\text { Hours }\end{array}$ & 52 & $9-408$ & 399 & 48 \\
\hline
\end{tabular}

\section{Results}

During the study period 154 patients were admitted with diagnosis of severe preeclampsia to the UCIGO, it is worth mentioning that there was just one maternal death, with a mortality of $0.65 \%$. This death happened 45 minutes after the admission and was related to mixed refractory lung oedema that in a strict way does not correspond to the Unit. There was not any fetal loss related to severe preeclampsia.

\section{Discussion and conclusion}

In 1997, a diagnosis and treatment protocol for severe preeclampsia was established and it called "TOLUCA": Organized Treatment With Guidelines Using Adequate Criteria/Tratamiento Organizado con Lineamientos Utilizando Criterios Adecuados, endorsed by Autonomous State of Mexico University, with headquarters in the Obstetric/Gynecology Hospital of the Maternal and Child Institute of Mexico State/Instituto Materno Infantil del Estado de México(IMIEM) in Toluca city, capital of Mexico State. ${ }^{14,15}$ First, a certified course of 1 year of duration was developed. In March 2007, it was restructured as specialty endorsed by Autonomous National University of Mexico with headquarters in Obstetric Critical Care Unit of "Hospital General de México Dr. Eduardo Liceaga" (UCIGO). This novel specialty called Obstetric Critical Care/Medicina Crítica en Obstetricia, has filled an educational gap, considering that medical and surgical treatment of preeclamptic patients frequently was based just in personal communications, nowadays this residency program avoid this anecdotic criteria. This program has 3 objectives:
a. Decrease the maternal and fetal mortality.
b. Education of human resources highly specialized.
c. Publication of the results in scientific Journals.

"Critical" is the sudden, paroxysmal, abrupt, that appears in crisis. The "critical" is also the decisive, unique, unrepeatable moment, and if we do not act with adequate decision, the inertia decides the situation. Educating the health personal in preeclampsia, obstetric haemorrhage and sepsis, as also the principal acute complications during pregnancy and puerperium, throughout this program of Obstetric Critical Care, added to the community participation in recognizing the risk signs during pregnancy, influence positively on maternal mortality. ${ }^{16,17}$ Obstetric Critical Care is oriented to treat the physiopathological acute alterations that threaten life in pregnant women with diseases or unfavorable obstetric events. ${ }^{18}$ This program allows Mexico being the first country worldwide implementing an academic program of high level addressed to the women requiring critical care. ${ }^{19}$ Unfortunately, maternal mortality, is also influenced of inadequate political decisions. ${ }^{20,21}$

\section{Acknowledgments}

None.

\section{Conflicts of interest}

The authors declare there is no conflict of interests.

\section{References}

1. American College of Obstetricians and Gynecologist. Task Force in Hypertensión in pregnancy. 2013.

2. Díaz de León-Ponce MA, Briones-Garduño JC, Meneses-Calderón $\mathrm{J}$, et al. Microangiopatía trombótica y hemólisis intravascular en hipertensión por embarazo. La mentira del síndrome de HELLP. Cir Ciruj. 2006;74(3):211-215. 
3. Abad Martínez L, Comino Delgado R, López G. Obstetricia y ginecología. Barcelona (España) Ariel, Spain; 2004.

4. Alvarado Alva JC. Manual de obstetricia. Lima (Perú). Apuntes Médico del Perú; 1998.

5. Schwarcz R. Obstetricia. El Ateneo, Buenos Aires, Argentina; 1983.

6. Briones JC, Castañón JA, Díaz de León M, et al. Velocidad de flujo sanguíneo cerebral en la preeclampsia-eclampsia. Prog Obstet Ginecol. 2000;43(10):511-520.

7. Meneses Calderón J, González Vargas O, Iván González J, et al. Programa de Rescate en la Disfunción Neurológica Grave en el Embarazo Complicado (PREDINEC). Revista de la Asociación Mexicana de Medicina Crítica y Terapia Intensiva. 2008;22(2):80-85.

8. Briones-Garduño JC, Castro-Nuño J, Díaz de León-Ponce $\mathrm{M}$, et al. Monitoreo hemodinámico con bioimpedancia torácica en pacientes con preeclampsia severa. Revista de la Asociación Mexicana de Medicina Crítica y Terapia Intensiva. 2012;26(4):201-208.

9. Foley MR. Obstetric Intensive Care Manual. 3rd edn. New York: McGraw-Hill publishers; 2011.

10. Belfort M, Saade G, Foley M, et al. Critical Care Obstetrics. 5th edn. Singapore: Wiley-Blackwell; 2010.

11. Briones-Garduño JC, Díaz de León-Ponce M, Bravo-Topete E, et al. Medición de la fuga capilar en la preeclampsia-eclampsia. Cir Ciruj. 2000;68(5):194-197.

12. Viruez-Soto JA, Briones-Garduño JC, Díaz de León-Ponce MA, et al. Optimización del gasto cardiaco en preeclampsia severa. Rev Asoc Mex Med Crit y Ter Int. 2014;28(4):216-220
13. Herrera-Gallardo C. Corticoides en el síndrome HELLP anteparto. Rev Obstet Ginecol Hosp Santiago Oriente Dr. Luis Tisné Brousse. 2006;1(1):72-76.

14. Briones-Garduño JC, Gómez-Bravo E, Ávila-Esquivel F, et al. Experiencia TOLUCA en preeclampsia-eclampsia. Cir Ciruj. 2005;73:101-105.

15. Herrera-Villalobos JE, Adaya-Laythe E, Ley-Chávez E. Medicina crítica en obstetricia: una realidad en México. Gaceta Médica de México. 2002;138(5):503-504.

16. Gómez-Bravo Topete E, Briones-Garduño JC, Castanón-Gonzáles JA, et al. Medicina crítica en obstetricia. Impacto de un programa educativo. Rev Asoc Mex Med Crity Ter Int. 2001;15(4):126-129.

17. Díaz de León-Ponce MA, Briones-Garduño JC. Medicina Crítica en Obstetricia, una nueva especialidad. Cir Ciruj. 2006;74(4):223-.224.

18. Guerrero-Hernández A, Briones-Vega CG, Díaz de León-Ponce MA, et al. Cuidados intensivos en ginecología y obstetricia en el Hospital General de México. Rev Asoc Mex Med Crit y Ter Int. 2011;25(4):211-217.

19. Briones-Garduño JC, Díaz de León-Ponce MA. Muerte materna y medicina crítica. Rev Asoc Mex Med Crit y Ter Int. 2011;25(2):56-57.

20. Díaz de León-Ponce MA, Briones-Garduño JC. La muerte materna indirecta en ocasiones puede ser directa o un incidente adverso. Rev Asoc Mex Med Crit y Ter Int. 2014;28(2):95-99.

21. Díaz de León-Ponce MA, Briones-Garduño JC. La decisión médica no influye en la mortalidad materna, la que determina ésta es la decisión política. Rev Asoc Mex Med Crit y Ter Int. 2014;28(3):195-198. 